УДК 631.51

(C) 2014

Соколовська І. М., кандидат сільськогосподарських наук

Кіровоградська державна сільськогосподарська дослідна станція НААН

\title{
ДИНАМІКА ПОПУЛЯЦІЙ ДЕЯКИХ БУР'ЯНІВ В АГРОФІТОЦЕНОЗАХ ПШЕНИЦІ ЯРОЇ
}

\section{Рецензент - кандидат сільськогосподарських наук В. О. Курцев}

Дослідження сучасного стану популяцій бур'янів в агроценозах має суттєве значення для прогнозування подальшого їх розвитку й впливу на врожайність, якість і продуктивність сільськогосподарських культур. На початку формування агрофітоиенозу пшениці ярої найбільш чисельною групою бур'янового компоненту були популячії ярих малолітніх бур'янів. Вони не складали конкуренції культурним рослинам, закінчуючи свій життєвий ичикл раніше, тому не мали істотного впливу на формування врожаю основної культури. Популячії коренепаросткових багаторічних бур'янів (будяк польовий, осот польовий, молочай, березка польова) у ией період формували найменш чисельну групу сегетальної рослинності, проте вони відрізнялися високою екологічною стійкістю, показниками життєвості та високою здатністю конкурувати з культурними рослинами, тому завдавали найбільшої шкоди посівам пшениці ярової. Без проведення правильних і своєчасних агротехнічних заходів популяиії цієєї групи рослин набували екологічної стійкості й мали значний вплив на формування агрофітоценнозу і врожаю ярої пшениці.

Ключові слова: популяції бур'янів, малолітні бур'яни, багаторічні бур'яни, чисельність популяиії, агрофіточеноз.

Постановка проблеми. Популяційні дослідження $\epsilon$ необхідною частиною моніторингу популяцій, тобто системи визначення перебування популяції нині й перспективи її розвитку.

Всі показники, що характеризують популяцію, досить мінливі й повинні вивчатися в динаміці. Особливості морфогенезу особин до певної міри $\epsilon$ також популяційною характеристикою, поскільки кожній популяції властиві свої особливості морфогенетичного розвитку.

Вивчення впливу абіотичних факторів (температурного, світлового режиму, вологості, складу та особливостей грунту тощо) на динаміку популяційних показників, а також вплив на ці показники біотичних компонентів біоценозу, насамперед інших видів рослин, дає змогу визначити шляхи зміни ценопопуляцій, прогнозувати можливі змін в їх розвитку.

Тому дослідження сучасного стану популяцій бур'янів в агроценозах має неабияке значення для прогнозування подальшого їх розвитку i впливу на врожайність, якість і продуктивність сільськогосподарських культур [1, 3, 4].

Аналіз основних досліджень і публікацій, в яких започатковано розв'язання проблеми. Бур'яни завдають чималої шкоди сільськогосподарському виробництву. Збитки від них перевищують втрати від комах, хвороб, непогоди разом узятих. Особливо велику загрозу бур'яни становлять для культурних рослин на ранніх етапах їх вегетації.

У посівах польових культур бур'яни не тільки знижують урожайність основної й додаткової продукції, але й потребують додаткових витрат, роблять важким виконання деяких польових робіт. Втрати від бур'янів можуть досягати $10-70 \%$ врожаю $[2,5]$.

Вважається, що за оптимально допустимої рівноваги між культурними рослинами й бур'янами користь від останніх значно перевищує шкоду, - вони захищають проростки культурних рослин від окремих несприятливих умов, сприяють процесам грунтоутворення, захищають грунт від ерозії, крім того багато 3 них $є$ медоносними i кормовими рослинами.

У системі агротехнічних заходів, спрямованих на отримання високих урожаїв культурних рослин, питання розвитку і популяційно-видового складу бур'янів під впливом екологічних факторів вивчено недостатньо $[2,5]$.

Мета досліджень. У зв'язку з цим нами в умовах північно-центральної помірно посушливої підзони північної степової зони Україна проводився моніторинг стану популяцій найбільш поширених бур'янів у посівах сільськогосподарських культур.

Завданнями досліджень передбачалося:

- провести моніторинг забур'яненості посівів зернових і просапних культур;

- вивчити стан популяцій найбільш поширених бур'янів у посівах зернових і просапних культур;

- визначити перспективи розвитку популяцій досліджуваних бур'янів і скласти рекомендації $з$ питання регулювання та контролю їх чисельності в посівах сільськогосподарських культур. 


\section{СІЛЬСЬКЕ ГОСПОДАРСТВО. РОСЛИННИЦТВО}

Матеріали і методи досліджень. Дослідження проводилися протягом 2010-2013 років. Динаміку кількісного складу бур'янових рослин в агрофітоценозі пшениці ярової вивчали в Свердловському та Ровеньківському районі Луганської області. Дослідження проводили в агрофітоценозах фермерських господарств із короткою ротацією сівозмін. Видовий склад вивчали на необроблених гербіцидами ділянках. Агротехнічні заходи виконувалися в одні й ті ж терміни. Заходів стосовно догляду за посівами не проводили. Контролем слугували необроблені ділянки (перелоги та міжсегетальні екотопи).

Результати досліджень. На початку літа в агрофітоценозах пшениці ярої (перша-друга декади червня) видовий склад популяцій бур'янових рослин був представлений такими основними екологічними групами: малорічними зимуючими та ярими й багаторічними бур' янами (див. табл.).

За першого обліку бур'янів (перша декада червня) найбільш чисельну групу складали популяції ярих малолітніх бур'янів (32\%) - редька дика (Raphanus raphanistrum), плоскуха звичайна (Echinochloa crus-galli L.), лобода біла (Chenopodium album), щириця звичайна (Amaranthus retroflexus), гірчак березковидний (Polygonum convolvulus L.), латук дикий (Lactuca serriola), мишій сизий (Setaria glauca L.), чина бульбиста (Lathyrus tuberosum L.) та ін. Популяції цих видів бур'янів не становили конкуренції рослинам агропопуляції, вони закінчували свій життєвий цикл раніше за культурні рослин, тому істотно не впливали на формування врожаю пшениці ярої.

Наступною за чисельністю видів була група популяцій зимуючих та озимих бурянів (29\%) фіалка польова (Viola arvensis Murr.), вероніка плющелиста (Veronica hederifolia L.), підмаренник чіпкий (Galium aparine L.), грицики звичайні
(Capsella bursa-pastoris L.), талабан польовий (Thlaspi arvense L.), глуха кропива стеблообгортна (Lamium amplexicaule), рутка лікарська (Fumaria officinalis). Початок весняної вегетації цих рослин відбувався на 5-7 діб раніше, ніж рослин пшениці ярої; їх активний ріст і розвиток на початку життєвого циклу надавав їм можливість конкурувати за фактори середовища в першій половині вегетації агрофітоценозу. Однак термін вегетації озимих і зимуючих бур'янів коротший за термін вегетації популяції культурних рослин, тому на формування врожаю зерна ця група сегетальної рослинності також значного впливу не мала (рис. 1).

Найменш чисельну групу малолітніх бур'янів становили ефемери. Популяція зірочника середнього (Stellaria media L.) складала не більше $2 \%$ від загальної чисельності даної групи рослин, інші ж бур'янові рослини ранньої й короткої вегетації були представлені поодинокими рослинами.

Коренепаросткові багаторічні бур'яни (будяк польовий (Cirsium arvense), осот польовий (Sónchus arvense), березка польова (Convolvulus arvensis L.) становили третю за чисельністю групу бур'янів (23\%). Рослини даної групи мали велику здатність конкурувати 3 культурними рослинами й завдавали посівам найбільшої шкоди. Популяції цих бур'янів відрізнялися невисокою насінною продуктивністю.

Розмножувалися переважно корінням, що давало їм можливість утворювати паростки з бруньок головного кореня або всієї кореневої системи. Небезпека забур'янення посівів, наприклад, осотом польовим, полягала в крихкому поверхневому корінні, здатному навіть від невеликих уламків давати поросль, а будякапольового, берізки польової - в досить довгому корінні.

\section{Видовий склад популяцій бур'янових рослин агрофітоценозу пшениці ярої}

на початку літа, 2010-2011 pp.

\begin{tabular}{|c|c|c|c|c|c|}
\hline \multicolumn{3}{|c|}{ Малолітні } & \multicolumn{3}{|c|}{ Багаторічні } \\
\hline зимуючі, озимі & ярі & ефемери & $\begin{array}{c}\text { корене- } \\
\text { паросткові }\end{array}$ & $\begin{array}{c}\text { корене- } \\
\text { стриженеві }\end{array}$ & $\begin{array}{l}\text { корене- } \\
\text { вищні }\end{array}$ \\
\hline $\begin{array}{c}\text { фіалка польова, } \\
\text { вероніка плющелиста, } \\
\text { підмаренник чіпкий, } \\
\text { грицики звичайні, } \\
\text { талабан польовий, } \\
\text { глуха кропива } \\
\text { стеблообгортна, } \\
\text { рутка лікарська }\end{array}$ & $\begin{array}{c}\text { редька дика, } \\
\text { плоскуха звичайна, } \\
\text { лобода біла, щири- } \\
\text { ця звичайна, гірчак } \\
\text { березковидний, } \\
\text { латук дикий, } \\
\text { мишій сизий, } \\
\text { чина бульбиста }\end{array}$ & $\begin{array}{l}\text { зірочник } \\
\text { середній }\end{array}$ & $\begin{array}{c}\text { березка } \\
\text { польова, } \\
\text { осот польо- } \\
\text { вий, будяк } \\
\text { польовий, } \\
\text { молочай }\end{array}$ & $\begin{array}{c}\text { кульбаба } \\
\text { лікарська, } \\
\text { полин білий }\end{array}$ & $\begin{array}{c}\text { пирій } \\
\text { повзучий }\end{array}$ \\
\hline
\end{tabular}




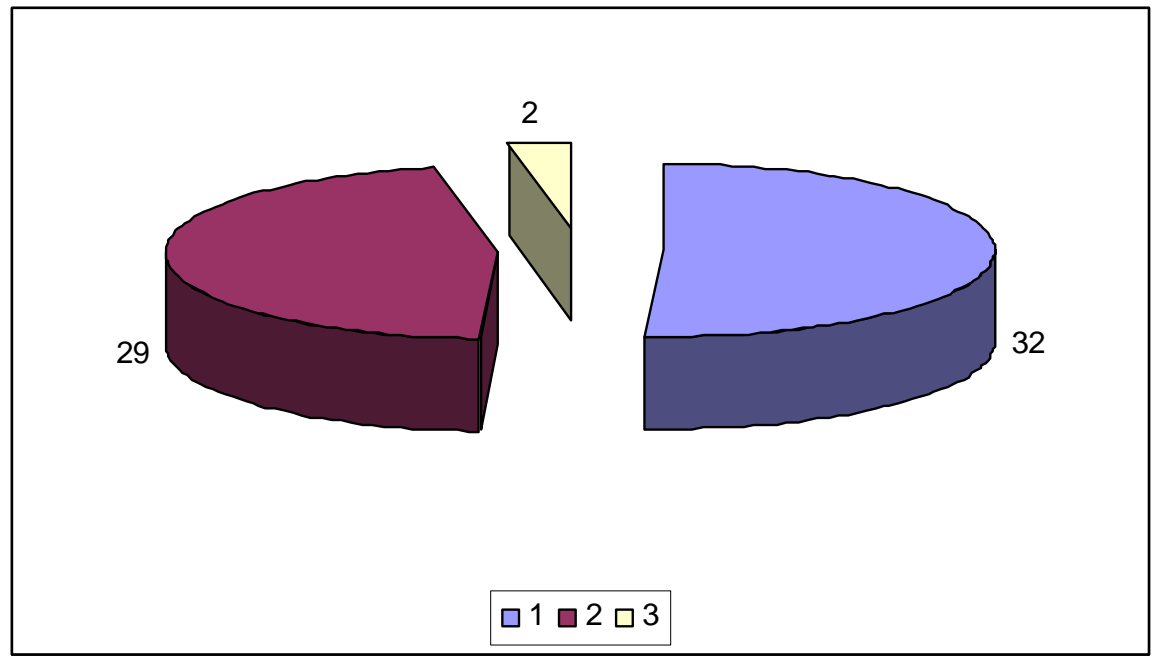

Рис. 1. Видовий склад популяцій малолітніх бур'янів у агрофітоценозі пшениці ярої:

1 - зимуючі та озимі бур'яни;

2 - ярі бур'яни;

3-ефемери.

Механічне пошкодження коріння коренепароскових бур'янів не тільки не пригнічувало їх ріст й розвиток, а, навпаки, стимулювало ще інтенсивніше паросткоутворення. Висока їх життєздатність пов'язана 3 міцною кореневою системою, а в осоту польового - 3 досить високою фотосинтезуючою активністю. Враховуючи неабияку біологічну життєздатність коренепароскових бур'янів, неможливо швидко нейтралізувати даний тип забур'яненості навіть досить ефек- тивними гербіцидними препаратами (рис. 2).

Кількісний склад популяцій кореневищних бур'янів (пирій повзучий (Elytrigiarepens L.), хвощ польовий (Equisétumarvénse) досягав лише $6 \%$, коренестриженевих $-8 \%$ від загальної чисельності популяцій сегетальної рослинності агрофітоценозу пшениці озимої. Їх наявність, навіть у незначній кількості завдавала чималої шкоди формуванню рослин агропопуляції та отриманню високого врожаю зерна.

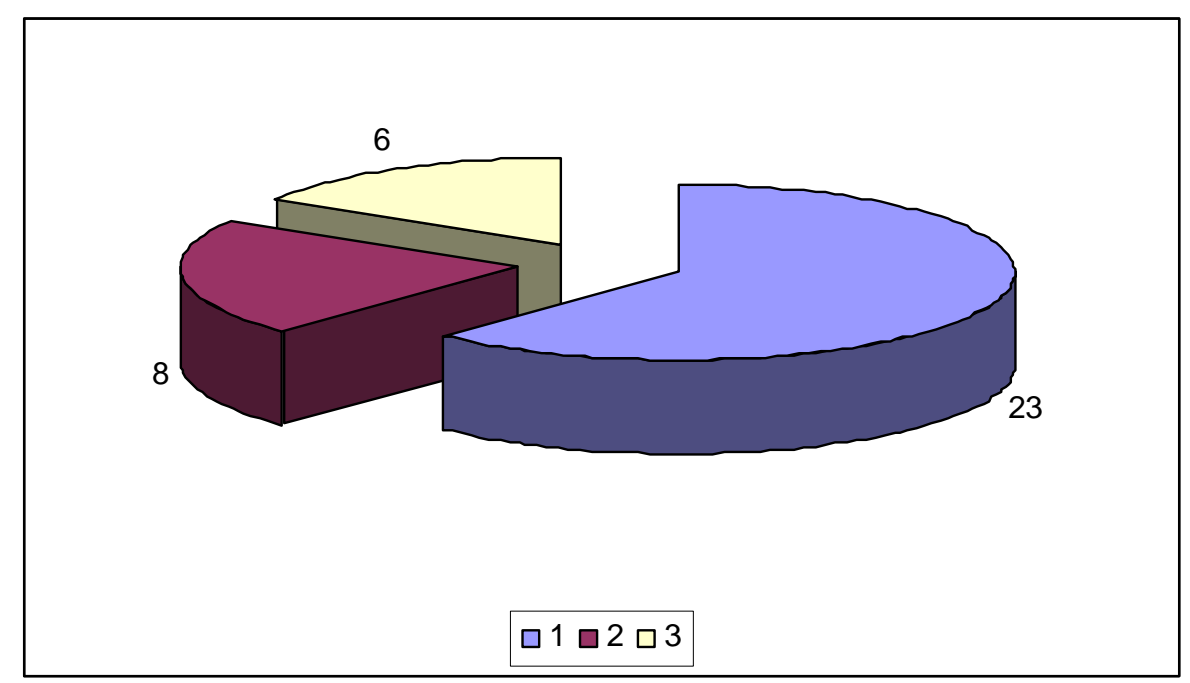

Рис. 2. Видовий склад популяцій багаторічних бур'янів у агрофітоценозі пшениці ярої:

1 - коренепаросткові бур'яни;

2 - коренестриженеві бур'яни;

3 - кореневищні бур'яни. 


\section{СІЛЬСЬКЕ ГОСПОДАРСТВО. РОСЛИННИЦТВО}

Другий облік був проведений через 25 днів після першого. За даними цього обліку, найбільш чисельну групу складали вже коренепаросткові бур'яни (34\%), чисельність популяцій ярих бур'янів скоротилася до $28 \%$, а також знизилася (до $23 \%$ ) чисельність озимих і зимуючих сегетальних рослин. Кількість популяцій коренестриженевих і кореневищних залишилася на тому ж рівні - 8 та $6 \%$.

За результатамитретього обліку, проведеного через 25 днів після другого, популяції коренепаросткових бур'янів становили найбільш чисельну групу сегетальних рослин даного періоду формування агрофітоценозу - $45 \%$. Популяції ярих бур'янів не перевищували $17 \%$ загальної кількості бур'янових рослин, а озимі та зимуючі, навпаки, скоротили свою чисельність (16\%), але вони не завдавали значної шкоди культурі. Коренестержневі бур'яни збільшили чисельність своїх популяцій на $25 \%$, а кореневищні - за рахунок могутнього розвитку кореневої системи збільшили свою чисельність у 2,5 разу порівняно 3 першим обліком.

Найбільшої шкоди посівам пшениці ярової наносили рослини коренепаросткових бур'янів. На відміну від культурних рослин і багаторічних бур'янів насіння деяких коренепаросткових бур'янів характеризувалося низькою первинною схожістю і досить тривалим періодом проростання, внаслідок чого їх насіння може зберігатися в грунті протягом десяти і більше років, не

\section{БІБЛІОГРАФІЯ}

1. Агаев М. Г. Уровни структурной организации агропопуляций / М. Г. Агаев // Агрофитоценозы и экологические пути повышения их стабильности и продуктивности: тезисы Всесоюзного совещания. - Ижевск, 1988. - С. 52-54.

2. Захаренко В. А. Борьба с сорняками / В. А. Захаренко, А. В. Захаренко // Защита и карантин растений. - 2004. - С. 62-142.

3. Косолап Н. П. Динамика группировок сорной растительности в агрофитоценозах озимой пшеницы зоны лесостепи Украины за последние 15 лет / Н. П. Косолап // Состояние и развитие втрачаючи схожості.

Проте не всім видам бур'янових рослин властива ця біологічна особливість. Деякі, наприклад, осот польовий, відрізняється дружним проростанням насіння i високою схожістю. Можна зробити висновок, що популяції коренепаросткових бур'яни відзначаються високою екологічною стійкістю.

Однією $з$ основних біологічних особливостей багаторічних бур'янів, що вкрай ускладнює боротьбу з ними, є їх здатність активно розмножуватися за допомогою органів вегетативного розмноження - кореневищ, кореневих паростків, розташованих, передусім, у верхній частині орного шару. Тому головне в боротьбі з ними виключити біосинтез i накопичення запасних поживних речовин у підземних органах, аби цим викликати виснаження рослин.

Висновок. Таким чином, протягом періоду розвитку агрофітоценозу пшениці ярої найбільшою мірою збільшувалася чисельність і щільність популяцій коренепаросткових бур'янів (23-45 \%). Дані популяції характеризувалися високими показниками життєвості й високою здатністю конкурувати 3 культурними рослинами. Без проведення правильних і своєчасних агротехнічних заходів популяції березки польової, осоту польового, будяка польового, молочаю набували екологічної стійкості й значно впливали на формування агрофітоценозу i врожаю пшениці ярої.

гербологии на пороге XXI столетия. - Голицыно, 2000. - C. 49-55.

4. Красноперов А. Г. Особенности сукцессии сорной растительности в зерновых агрофитоценозах / А. Г Красноперов // Сельскохозяйственная біологія. - № 1. - 2004. - С. 78-82.

5. Синещеков B. E. Сорные растения зерновых агроценозов в почвозащитном земледелии // В. Е. Синещеков, А. Г. Красноперов. - Новосибирск : РАСХН. Сиб. отд-е. СибНИИЗХим, 2005. $-120 \mathrm{c}$. 